\title{
PEMAKNAAN KECANTIKAN SEBAGAI PUTIH JEPANG DALAM IKLAN SHINZUI BODY CLEANSER
}

\author{
Anggry Windasari, Mutia Rahmi Pratiwi dan Amida Yusriana \\ Program Studi Ilmu Komunikasi, Fakultasi Ilmu Komputer, \\ Universitas Dian Nuswantoro (Udinus) Semarang \\ amida.yusriana@dsn.dinus.ac.id
}

\begin{abstract}
The Beauty Concept is changing from time to time, from the classic beauty that walks in harmony with the nature to the subjectivity of postmodern beauty. Nevertheless, the beauty standard is often constructed by the media by using certain type of models. The problem is this one standard is applied into all over the world. Indonesia is no exception. The Shinzui Body Cleanser's advertisement is one of the advertisement that construct this standard into consumer's mind. This advertisement claims to be made by Japanese nature's extracts and identified beauty as Japanese woman's white skin. Thus, this research aims to know how the consumer's reseption analysis towards the concept of beauty in the Shinzui advertisement are. This research uses reception analysis method by interviewing particular respondents. It uses the Encoding Decoding Model by Stuart Hall. Based on the theory, the result shows there are three categories in this advertisement. One person in the category of Dominant Hegemonic, one person in the category of Negotiated Reading and two persons in the category of Oppositional Reading.
\end{abstract}

\begin{abstract}
Abstrak
Konsep kecantikan terus mengalami perubahan, dari kecantikan klasik yang senada dengan alam hingga kecantikan postmodern yang begitu subyektif. Meskipun demikian, standar kecantikan seringkali dikonstruksi oleh media melalui penggunaan model - model perempuan dengan tipe tertentu. Yang menjadi persoalan adalah saat satu standar kemudian digunakan di seluruh dunia. Takterkecuali Indonesia yang mengalami pergeseran standar kecantikan. Iklan Shinzui Body Cleanser merupakan salah satu iklan yang membangun konstruksi tersebut kepada target konsumen Indonesia. Iklan ini menggunakan bahan - bahan alami Jepang dan berupaya mengidentikan kecantikan sebagai kulit putih wanita Jepang. Maka penelitian ini berusaha mengetahui bagaimana analisis resepsi konsumen terhadap konsep kecantikan iklan Shinzui. Penelitian ini menggunakan metode analisis resepsi dengan melakukan wawancara kepada responden yang telah memenuhi kriteria tertentu. Teori yang digunakan adalah Teori Interpretasi dan Negosiasi Makna oleh Stuart Hall. Hasil menunjukkan bahwa terdapat 3 kategori resepsi dalam iklan Shinzui pada penonton. Satu orang dalam kategori Dominant Hegemonic, satu orang dalam kategori Negotiated Reading dan dua orang dalam kategori Oppositional Reading.
\end{abstract}

Keywords: Shinzui, The Standard of Beauty, Reception Analysis 


\section{PENDAHULUAN}

Salon, produk pemutih, skin care dan produk anti penuaan dini merupakan bagian dari industri kecantikan yang tidak terlepas dari perempuan. Perempuan dan kecantikan dapat diibaratkan seperti dua sisi mata uang yang tidak dapat dipisahkan. Bila muncul pertanyaan kepada masyarakat luas siapakah yang cantik? Apakah cantik diperuntukan bagi laki-laki atau perempuan? maka konsep cantik sepenuhnya akan ditujukan pada perempuan. Karena budayayang membentuk hanya ada perempuan cantik bukan laki-laki cantikyang kini mulai menjadi perbincangan. Konsep kecantikan pada perempuan telah berevolusi menjadi bagian dari budaya populer masyarakat dunia yang dipuja dan didambakan. Bahkan tak sedikit perempuan yang mengorbankan cukup banyak uang untuk memperoleh kecantikan.

Tubuhperempuandikatakancantiktidak hanya berdasarkan kecantikan wajahnya, tetapi juga identik dengan kulit yang putih, mulus dan kencang, serta bentuk tubuh yang menonjolkan lekukan dan kemontokan organ tertentu, seperti dada dan pinggul, bibir yang sensual, serta segalah hal yang terkait dengan organ tubuh perempuan (Kasiyan, 2008: 281).

Menurut Bungin (2008: 221) bahwa kecantikan direpresentasikan dalam rupa kulit whiteness (menjadi putih), rambut hitam, tebal dan lurus, bertubuh slim, memiliki kesegaran tubuh, adanya kebersihan, kemewahan, keanggunan dan berparas menawan. Sementara itu, Prabasmoro (2003: 106) dalam bukunya mengungkapkan bahwa kecantikan dinaturalisasikan dengan warna kulit putih.

Hingga saat ini standar kecantikan yang berkembang di masyarakat adalah "Beauty is pain” (Cantik itu sakit). Satu kalimat "sakti” ini yang hingga kini terus dipegang teguh oleh sebagian besar perempuan. Kalau mau cantik maka sedikit menahan sakit bukan menjadi masalah besar. Inilah yang kemudian menyebabkanperempuanmelakukanapapun bahkan hingga melakukan upaya berat yang menyakitkan agar dianggap cantik oleh lingkungan sekitarnya dimana mereka selalu berinteraksi. Upaya yang dilakukan dimulai dengan penggunaan kosmetik dengan tujuan menghaluskan atau menyamarkan noda atau memutihkan; melangsingkan badan melaui olahraga maupun diet ketat untuk dapat menunjukan kecantikan melalui bentuk tubuh ideal; hingga operasi plastik yang dilakukan untuk merombak yang dianggap tidak layak cantik menjadi masuk dalam kategori ideal atau proporsional disebut cantik. Hal ini pun semakin meneguhkan bahwa penampilan fisik menjadi syarat utama untuk menjadi cantik.

Pada kenyataannya kecantikan adalah salah satu bentuk konstruksi media massa, salah satunya diwujudkan dalam bentuk iklan. Menurut Bungin (2008: 79), Iklan adalah bagian penting dari serangkaian kegiatan mempromosikan produk yang menekankan unsur citra. Dengan demikian, objek iklan tidak sekedar tampil pada wajah yang utuh, akan tetapi melalui proses pencitraan sehingga citra produk lebih mendominasi bila dibandingkan dengan produk itu sendiri. Pada proses ini cita produk diubah menjadi citra produk. Perjalanan perubahan dari cita menjadi citra merupakan persoalan interaksi simbolis dimana objek iklan dipertontonkan.

Makna kecantikan sendiri yang hadir saat ini merupakan realitas konstruksi dari iklan, maka dari itu model iklan yang cantik selalu dimunculkan dalam iklan-iklan yang menyasar ke segmen perempuan. Contohnya saja untuk iklan produk kecantikan wardah maka brand ambassador yang muncul dalam iklan adalah Dewi Sandra, Zaskia Sungkar, Natasya Rizki yang notabene adalah wanita cantik. Dalam iklannya, ponds pun juga menggunakan model yang cantik diantaranya Natasya Rizki, Eriska Reinisa, dan Nurul Fitri. Model iklan yang muncul dalam contoh produk wardah dan ponds dapat dikategorikan cantik dan putih sehingga menjadi pendukung produknya yang bertujuan untuk memutihkan karena putih = cantik.

Menggunakan perempuan yang cantik merupakan upaya mengkonstruksi pikiran 
konsumen untuk menjadikan wajah tersebut sebagai standar dalam masyarakat. Menurut Bungin (2008: 37), iklan-iklan yang besar dengan daya tarik yang besar, merupakan iklan dengan konstruksi yang besar pula. Dalam perpanjangannya, perempuan tidak hanya muncul dalam produk kecantikan atau yang berbau wanita, perempuan cantik selalu ditampilkan dalam model iklan. Perempuan dan bagian-bagian tubuh perempuan dapat menjual segala macam kebutuhan mulai dari kebutuhan primer hingga sekunder, dari yang berbentuk makanan, peralatan rumah tangga, kosmetik, mobil bahkan hingga bangunan siap huni (ruko dan rumah).

Banyaknya iklan menggunakan perempuan selaras dengan pernyataan Ann Marie Britton dalam penelitiannya berjudul The Beauty Industry's Influence on Woman in Society bahwa perempuan saat ini secara konsisten diingatkan tentang apa yang dianggap sebagai 'cantik'. Ada ribuan iklan yang mempromosikan citra kecantikan yang sulit dimengerti kepada perempuan berbagai usia, bentuk dan ukuran. Dengan menampilkan foto hasil photoshop dan komputer dan menambahkan jumlah model dalam iklan, masyarakat telah membangun standar kecantikan yang tidak mungkin hingga kemudian mempengaruhi perasaan kurang di antara para perempuan (Britton, 2012: 4).

Selaras dengan kecantikan yang 'tidak mungkin' tersebut, kecantikan yang dikonstruksikan tersebut bersifat tunggal. Hal ini tidak sesuai dengan negara Indonesia. Negara Indonesia sendiri sebagai sebuah negara yang luas dengan berbagai macam suku, etnis, ras dan agama di dalamnya direpresentasikan secara sederhana dalam media, utamanya iklan untuk menampilkan konsep kecantikan bagi perempuan (Bungin, 2008: 113).

Iklan di berbagai media di Indonesia menunjukan bahwa perempuan cantik itu direpresentasikan sebagai bahasa yang universal, yakni dengan pergeseran dari kulit langsat atau sawo matang, anggun seperti putri keraton, menjadi kulit putih yang 'mempesona' barat dan berpemikiran bebas (dimana ia tidak perlu memikirkan sebuah tradisi yang kemudian harus dihubungkan dengan apa yang akan mereka lakukan) seperti dunia barat (Eropa dan Amerika) (Yulianto, 2007: XII). Sehingga apa yang ditampilkan oleh iklan ini nyatanya hanya mewakili sebagian kecil dari realitas masyarakat Indonesia.

Standar kecantikan sejatinya selalu berevolusi. Konsep kecantikan juga bisa dibedakan antara yang klasik, modern, dan postmodern. Kecantikan klasik lebih mengarah pada ukuran-ukuran tubuh yang proporsional sesuai dengan konsepsi ideal yang digariskan oleh budaya, dan perpaduan antara kecantikan fisik dan mental (inner beauty), serta menekankan pada keselarasan hubungan dengan alam. Konsep kecantikan tradisional pada dasarnya berpijak kepada prinsip harmoni yang terkait secara struktural antar bagian tubuh sebagai efek alamiah dari anatomi dan fisiologis tubuh manusia (Sudiarta, 2006: 56). Kecantikan tradisional banyak mengambil perumpamaan dari keindahan alam.

Kecantikan modern, lebih mengarah pada keseragaman atau universalitas, seperti kulit putih, dan ukuran-ukuran tubuh yang proporsional, dan semuanya mengarah pada hal-hal yang modern. Sedangkan kecantikan postmodern, adalah kecantikan yang mengacu pada makna pluralitas, heterogenitas dan bersifat sangat subyektif. Kecantikan sesungguhnya juga merupakan bagian dari sistem budaya yang direpresentasikan melalui simbol. Simbol dalam tubuh adalah sesuatu yang disampaikan, sekaligus yang disembunyikan. Karena itu maka dikatakan bahwa tubuh manusia yang awalnya adalah tubuh alami (natural body), kemudian dibentuk menjadi tubuh sosial atau fakta sosial (Abdullah, 2006: 138). Namun, masingmasing budaya memiliki kekhasan (tipikal) kecantikan yang ditunjukkan melalui ciri-ciri fisik dan nonfisik, yang bersifat komulatif, mencakup ukuran-ukuran tubuh tertentu yang ideal, misalnya kulit putih.

Meskipun banyak kampanye yang berusaha membangun era kecantikan postmodernisme yang mengapresiasi subyektifitas kecantikan, pada kenyataanya 
masyarakat masih terjebak dalam kecantikan modern yang homogen. Yulianto (2007: 36) mengatakan bahwa idealisme kecantikan perempuan kini diidentikkan dengan kulit putih atau wajah Indo. Pada beberapa penelitian tentang konsep kecantikan yang ada di masyarakat pada beberapa tahun belakangan ini menunjukkan hal berbeda dengan konsep literatur Jawa tentang kecantikan (Yulianto, 2007: 14).

Dengan kata lain, hanya ada satu standar warna kulit bagi kecantikan perempuan, yaitu kulit putih. Kulit putih dan cantik dianggap sebagai ras superior, karena itu dinormalkan dan diidealkan, bahkan, putih dan keputihputihan adalah halyang signifikan, bukan saja dalam katagori sebagai ras, melainkan juga dalam definisi dan konstruksi femininitas, seksualitas, dan domestisitas perempuan.

Media-media yang ada di masyarakat memiliki tugas untuk menyebarkan informasi tidak hanya berdasarkan fakta namun juga berdasarkan konstruksi budaya yang historis. Konstruksi kecantikan tunggal tersebut secara tidak langsung telah merepresentasikan kondisi sosial masyarakat yang hanya berpatok pada struktur budaya historis dan tidak dibandingkan dengan sebenarnya. Pada akhirnya konstruksi realitas yang ditampilkan oleh media bersifat tidak adil untuk sebagian orang yang tidak terwakili dalam media karena media hanya akan mewakili suara mayoritas yang dominan.

Sebagai salah satu media komunikasi, iklan menjadi salah satu alat dalam mengkomunikasikan pesan. Iklan tidak hanya terbatas pada tahap menawarkan produk namun, sampai pada taraf membujuk untuk membeli produk yang diiklankan (Jeffkins, 1996: 11). Sebuah iklan yang nampak sederhana sekalipun, masih terdapat unsur makna berlapis. Iklan tidak bebas nilai, sebaliknya dipenuhi berbagai kepentingan yang memberikan keuntungan dan kekuasaan pada pihak-pihak tertentu. Dengan potensi ini, iklan dapat hadir sebagai sebuah persoalan. Iklan bukan lagi hanya sekedar menjadi cermin bagi masyarakat, akan tetapi, masyarakat merupakan cermin iklan. Iklan merupakan pengkontruksi realitas yang diciptakan berdasarkan ideologi tertentu. Dengan demikian, iklan memiliki suatu bentuk "kekuasaan" dalam komunitas dalam masyarakat. Iklan berperan besar dalam menentukan kecenderungan, trend dan mode, bahkan membentuk kesadaran serta konstruksi berpikir manusia modern (Channey, 1996: 8).

Berbagai produk-produk pencerah atau pemutih kulit yang ada di Indonesia tidak sepenuhnya mewakili kebutuhan masyarakat Indonesia yang beragam dan terdiri dari berbagai ras dan etnis. Masyarakat Indonesia yang mayoritas memiliki ciri-ciri fisik berkulitsawo matang tidak direpresentasikan dalam berbagai macam produk pemutih kulit. Produk-produk kecantikan tersebut cenderung menampilkan model wanita cantik berkulit putih yang berambut lurus (Yulianto, 2007:36).

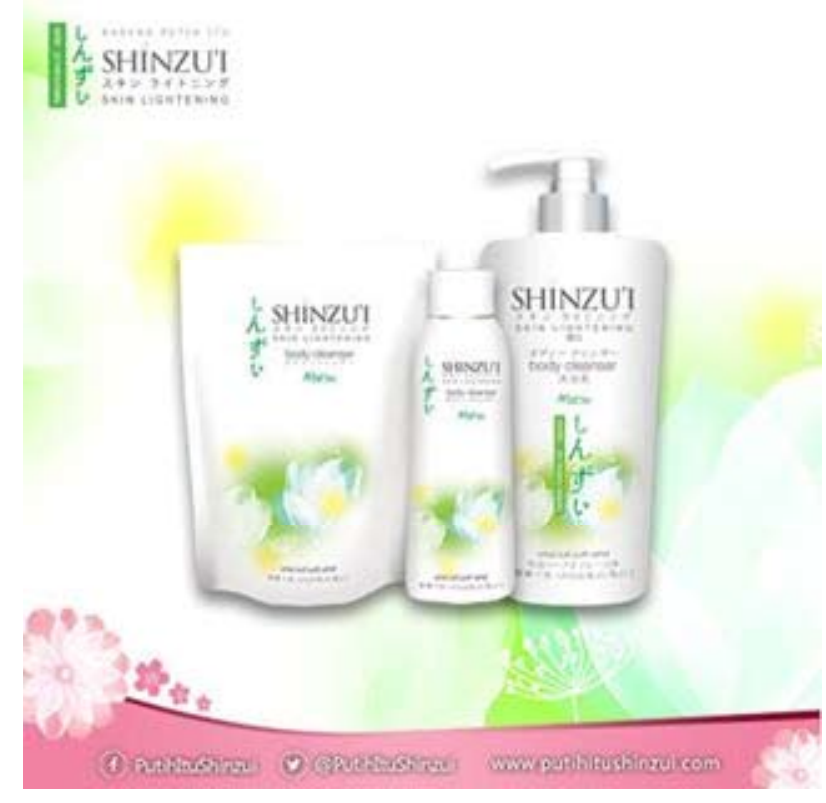

Dalam pembahasan ini, penulis memfokuskan pengaruh image kecantikan putih pada satu iklan tentang produk pemutih kulit yaitu sabun mandi Shinzui. Produk pemutih kulit seperti Shinzui Body Cleanser adalah Sabun cair yang membuat kulit bersih, efektif mencerahkan kulit secara alami. Sabun cair dengan keharuman bunga-bunga Jepang yang tetap akan meninggalkan keharuman mewah pada tubuh setelah mandi. Digunakan dengan cara dituangkan ke telapak tangan atau shower puff untuk busa yang lebih banyak. Dapat membersihkan dan memutihkan kulit 
dengan pemakaian teratur. Mengandung Herba Matsu Oil, Natural Whitening Extract yang diekstrak dari tumbuhan Matsutake Jepang. Berkhasiat membantu pembentukan melanin yang tidak berwarna sehingga kulit menjadi lebih cerah dan terlindung dari sinar UV. Dengan Kandungan Extract Bunga Sakura berfungsi untuk regenerasi sel kulit sehingga kulit tampak lebih bening dan kenyal. (http:// putihitushinzui.com/diakses pada tanggal 12 Juni 2016).

Produk shinzui mendapatkan Top Brand Award 2012 dengan Kategori Whitening Soap. Ajang penghargaan untuk merek-merek terbaik di Indonesia ini, diselenggarakan untuk ke-13 kalinya, di Hotel Mulia Senayan, Jakarta pada hari Selasa 7 Februari 2012. Pihak penyelenggara, lembaga riset Frontier Consulting Group dan majalah Marketing, melakukan survei di enam kota besar di IndonesiasepertiJakarta, Bandung,Semarang, Surabaya, Medan, dan Makassar dengan melibatkan lebih dari 2400 responden yang dilakukan secara random dan 1200 sampel secara booster. Penghargaan yang diberikan berdasarkan tiga parameter, yaitu : top of mind share, top of market share dan top of commitment share (http://bisniskeuangan. kompas.com, diakses tanggal 12 Juni 2016).

Shinzui juga telah mendekati customer dengan konsep putihnya melalui media sosial, diantaranya melalui instagram dan twitter. Melalui media sosial ini, Shinzui semakin menguatkan konstruksinya bahwa putih itu cantik tidak hanya melalui iklan yang ditampilkan namun juga melalui tampilan media promosi yang telah dipilih. Berikut ini adalah bentuk visualisasi media promosi shinzui:

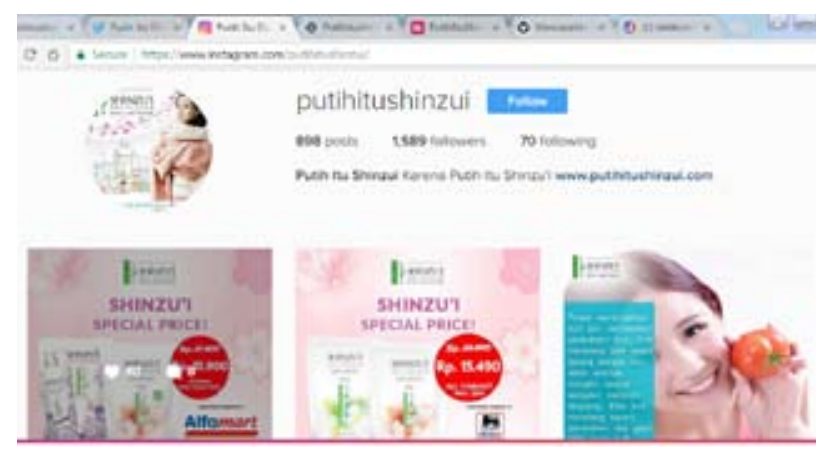

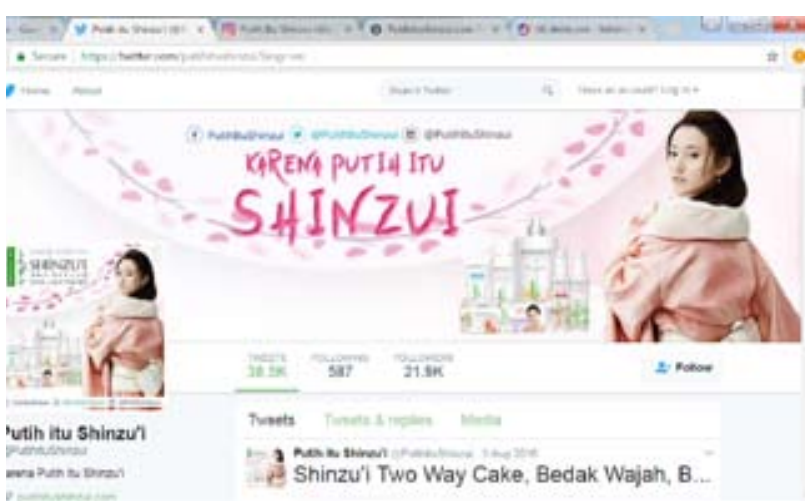

Iklan yang dibahas oleh penulis disini adalah Shinzui Body Cleanser edisi Skin Lightening. Iklan yang berdurasi sekitar 30 detik ini, menceritakan tentang seorang wanita Jepang yang berparas cantik dan berkulit putih sedang menikmati aktivitas mandinya di danau dengan menggunakan produk Shinzui Body Cleanser. Dalam iklan tersebut, sang wanita tampak rileks berenang, yang kemudian diakhiri dengan scene sang wanita bertemu dengan seekor kuda putih yang bersih. Iklan commercial Shinzui Body Cleanser ini berupaya mempersuasif khalayak tentang konsep kecantikan, yaitu berkulit putih dan putih yang dimaksud adalah seputih kulit wanita Jepang.

Berdasarkan gambar, atribut dan narasi dalam iklan tersebut, perempuan Indonesia sebagai konsumen target diajak untuk membeli sabun Shinzui agar menjadi mempesona dengan menjadi putih. Maka penelitian ini berusaha untuk memahami bagaimana resepsi penonton iklan terhadap standar kecantikan putih Jepang dalam iklan Shinzui edsisi Body Cleanser?

\section{KAJIAN PUSTAKA}

Pada umumnya, banyak orang berasumsi bahwa mengonsumsi media adalah aktivitas pasif. Karena audiens hanya duduk di depan televisi dan mengonsumsi tanpa benar-benar 'terjalin' atau beraktivitas. Hall berpendapat bahwa konsumsi bukanlah aktivitas pasif. Ini disebabkan menurutnya konsumsi media membutuhkan generasi pemahaman. Tanpa pemahaman, tidak akan ada konsumsi. Pemahaman, sebaliknya tidak dapat digenerasikan secara pasif. Karena tidak ada cara pasif untuk menerima suatu 
pesan - kita harus menciptakannya sendiri. Khalayak aktif tidak lagi dianggap sebagai jarum hipodermik yang langsung begitu saja menerima pesan dari media. Khalayak disini menggunakan field of experience dan frame of reference mereka. Sehingga Ideologi dominan dari media tidak lagi sekedar diterima oleh khalayak aktif. (Hall, 1980: p.128).

Istilah decoding encoding digunakan Hall untuk mengungkapkan bahwa makna dari teks terletak antara si pembuat teks (encoder dalam hal ini komunikator atau professional media) dengan pembacanya (decoder atau komunikan, dalam hal ini audiens media). Walaupun si pembuat teks sudah mengencode teks dalam cara tertentu, namun si pembaca akan men-decode-nya dalam cara yang sedikit berbeda. Ideologi dominan secara khusus dikesankan sebagai preferred readings (bacaan terpilih) dalam teks media, namun bukan berarti hal ini diadopsi secara otomatis oleh pembaca (McQuail, 2002: 388).

Teori Stuart Hall tersebut, tentang encoding dan decoding, mendorong terjadinya intepretasi-intepretasi beragam dari teks-teks media selama proses produksi dan resepsi (penerimaan). Dengan kata lain, makna tidak pernah pasti. Hall (1980: 136-138) menurunkan 3 intepretasi yang digunakan individu untuk menafsirkan atau memberi respons terhadap persepsinya mengenai kondisi dalam masyarakat, yaitu dominan/ hegemonic code adalah disini posisi audiens yang menyetujui dan menerima langsung apa saja yang disajikan oleh televisi, menerima penuh ideology yang dari program tayangan tanpa ada penolakan atau ketidaksetujuan terhadapnya. Negotiated code, penonton yang mencampurkan intepretasinya dengan pengalaman-pengalaman sosial tertentu mereka. Penonton yang masuk kategori negosiasi ini bertindak antara adaptif dan oposisi terhadap intepretasi pesan atau ideology dalam televisi. Oppositional code adalah ketika penonton melawan atau berlawanan dengan representasi yang ditawarkan dalam tayangan dengan cara yang berbeda dengan pembacaan yang telah ditawarkan. Tipe ini tidak merasakan kesenangan pada saat menonton televisi. Ia menolak sajian atau ideologi dominan dari televisi.

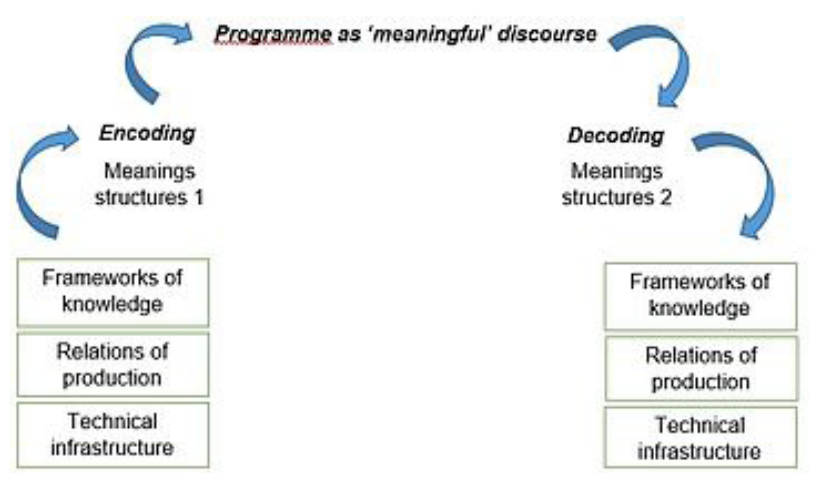

Sumber: https://educ5102.wikispaces.com/ Cultural+Studies+(Hall) diunduh tanggal 31 Maret 2017 pukul 11.32 WIB

\section{METODE}

Unit analisis dalam penelitian ini adalah iklan elektronik Shinzui Body Cleanser edisi Skin Lightening yang berdurasi 30 detik. Penelitian ini menggunakan pendekatan kualitatif, dimaksudkan untuk mengemukakan gambaran dan/atau pemahaman mengenai bagaimana dan mengapa suatu gejala atau realitas komunikasi terjadi (Pawito, 2007: 35).

Pendekatan yang digunakan dalam penelitian ini adalah analisis resepsi. Metode ini memandang khalayak sebagai pencipta aktif makna dalam kaitannya dengan teks. Hall menyatakan bahwa produksi makna tidak menjamin konsumsi makna sebagaimana yang dimaksudkan pengode karena pesan-pesan (dalam televisi), yang dikonstruksi sebagai sistem tanda bersifat polisemis, sehingga memiliki lebih dari sekedar serangkaian makna potensial (Barker, 2009: 35). Analisis resepsi yaitu makna media yang dinegosiasikan oleh individual berdasarkan pengalaman mereka. Dengan kata lain pesan-pesan media secara subjektif dikonstruksikan khalayak secara individual. Khalayak menerapkan berbagai latar belakang sosial dan kultural yang diperoleh sebelumnya untuk membaca teks, sehingga khalayak yang memiliki karakteristik yang berbeda akan memaknai suatu teks secara berbeda pula. 
Teknik pengumpulan data yang digunakan dalam penelitian ini adalah wawancara mendalam (in-depth interview). Wawancara dengan menggunakan pedoman wawancara (interview guide) pada umumnya dimaksudkan untuk kepentingan wawancara yang lebih mendalam dengan lebih memfokuskan pada persoalan-persoalan yang menjadi pokok minat penelitian. Hal demikian akan lebih mempermudah langkahlangkah sistematisasi data. Pedoman wawancara biasanya tidak berisi pertanyaanpertanyaan yang mendetail, tetapi sekedar garis besar tentang data atau informasi yang ingin didapatkan dari informan yang nantinya dapat dikembangkan dengan memerhatikan perkembangan, konteks, dan situasi wawancara. Dalam penelitian ini, individu diminta untuk memberikan penilaian mengenai konsep kecantikan yang ditawarkan oleh iklan Shinzui.

\section{Subjek Penelitian}

Dalam penelitian ini, penentuan subjek penelitian atau responden berdasar pada beberapa kriteria berikut ini:

1. Perempuan karier dengan latar belakang usia 20 - 35 tahun

2. Memiliki kemampuan finansial mandiri

3. Peduli terhadap penampilan dan tinggal di wilayah urban.

Pemilihan tersebut disesuaikan dengan target audience yang menjadi sasaran dari iklan Shinzui dan pernah atau rutin menggunakan sabun Shinzui.

Khalayak yang akan diteliti merupakan bagian dari interpretive communities. Interpretive communities merupakan kelompok yang saling berinteraksi, membentuk realitas dan pemaknaan umum, serta menggunakannya dalam pembacaan mereka (Littlejohn, 2005: 197). Interpretive communities berupaya untuk menjelaskan proses-proses sosial yang terlibat dalam menafsirkan teks-teks budaya. Makna berasal dari teks budaya yang tidak sepenuhnya subjektif maupun objek material; melainkan teks yang menjadi bermakna dikarenakan berbagai strategi interpretasi yang dilakukan olehanggota komunitas. Komunitas mengacu pada kesadaran bersama, yaitu: keyakinan, impian, atau identitas dalam populasi orangorang secara luas. Komunitas terkadang digunakan untuk menggolongkan situasi berdasarkan penggemar, subkultur, dan tipe lain dari kolektivitas sosial. (Littlejohn dan Foss, 2009: 554).

Pembaca merupakan anggota dari interpretive community, yaitu: kelompok yang saling berinteraksi, membentuk realitas dan pemaknaan umum, serta menggunakannya dalam pembacaan mereka sehingga pemaknaan berada dalam pembaca interpretive community. Seseorang tidak akan mendapatkan pemaknaan tunggal, tidak ada pemaknaan yang benar atau objektif dari teks namun sepenuhnya tergantung pada interpretasi audiens. Menurut Fish, penulis teks bukan merupakan sumber makna. Pembaca selalu merencanakan pemaknaan mereka kedalam fitur teks dan akhirnya hanya muncul pemaknaan diri mereka sendiri. Pembaca tidak pernah jauh dari teks, mereka selalu menanamkan pemaknaan mereka di dalamnya (Littlejohn, 2008: 135).

Dalam Littlejohn, (2008: 296-297), Fish menyatakan bahwa Interpretive community terdapat di sekitar media dan konten tertentu. Komunitas yang berkembang disekitar pola konsumsi bersama, mencakup pemahaman umum mengenai konten yang dibaca, dilihat atau didengar dan hasil bersama. Setiap orang dapat menjadi anggota dari berbagai interpretive community dan kelompok sosial tertentu, seperti keluarga, yang dapat menjadi persimpangan dalam suatu komunitas.

Thomas Lindlof menyoroti tiga genre interpretive community, karena interpretive community memiliki pemaknaannya sendiri mengenai media. Genre ini merupakan tipe umum dari hasil media yang diciptakan oleh interaksidalaminterpretive community, yaitu: content (isi), interpretasi, dan tindakan sosial. Genre pertama yang menunjukan interpretive community adalah content (isi), yang terdiri dari tipe-tipe program dan media lainnya yang dikonsumsi oleh komunitas. Komunitas tidak hanya memiliki ketertarikan yang sama dalam salah satu jenis media namun juga 
memiliki pemaknaan yang sama terhadap satu konten media. Genre interpretasi, berkembang di sekitar pemaknaan bersama. Anggota komunitas menafsirkan isi program dan media lain dengan cara yang sama. Hal ini berdampak pada perilaku mereka, terutama pada apa yang mereka katakan tentang media dan bahasa yang digunakan untuk menjelaskannyaadalah sama. Genretindakan sosial merupakan tatanan perilaku bersama terhadap media tertentu, tidak hanya pada bagaimana media dikonsumsi (kapan dan dimana isi media dibaca dan dilihat) namun juga cara isi media mempengaruhi perilaku anggota suatu komunitas.

Menurut Ien Ang dalam Downing, Mohammadi, dan kawan-kawan (1990: 160161), interpretive community menunjukan kelompokindividuyang membuat interpretasi umum pada teks (Radway, 1987). Subkultur (Hebdige, 1978) yang terdiri dari orang-orang yang berbagi pilihan untuk isi media tertentu. Komunitas atau subkultur tidak perlu secara fisik bersatu dalam satu lokasi namun secara geografi tersebar dan terdiri dari berbagai orang yang tidak saling mengenal namun secara simbolis dihubungkan dengan kepentingan bersama di produk media.

\section{Encoding: Iklan Shinzui Body Cleanser}

Encoding merupakan awalan untuk memahi teori encoding decoding. Sebelum meneliti resepsi khalayak yang merupakan bagian dari tahap decoding, maka perlu diketahui makna yang ingin disampaikan melalui iklan Shinzui Body Cleanser. Berikut adalah screen capture dari iklan visual Shinzui Body Cleanser:

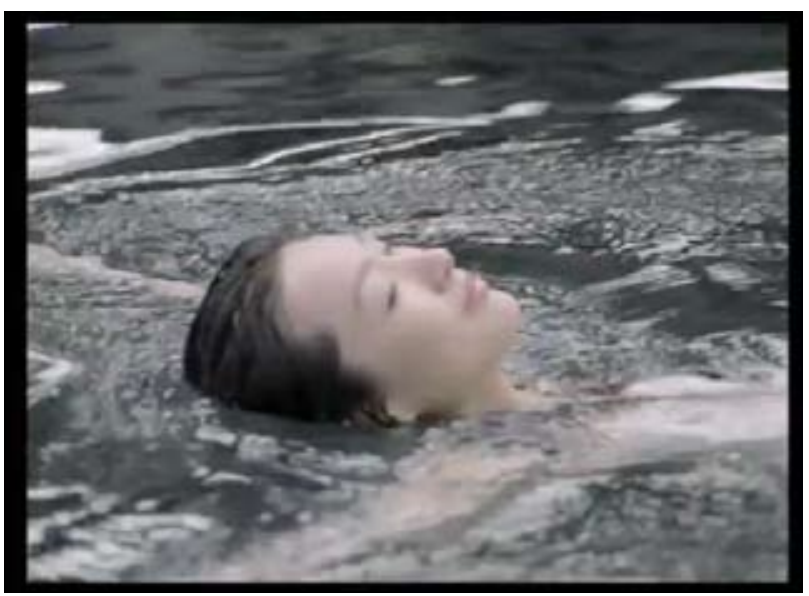

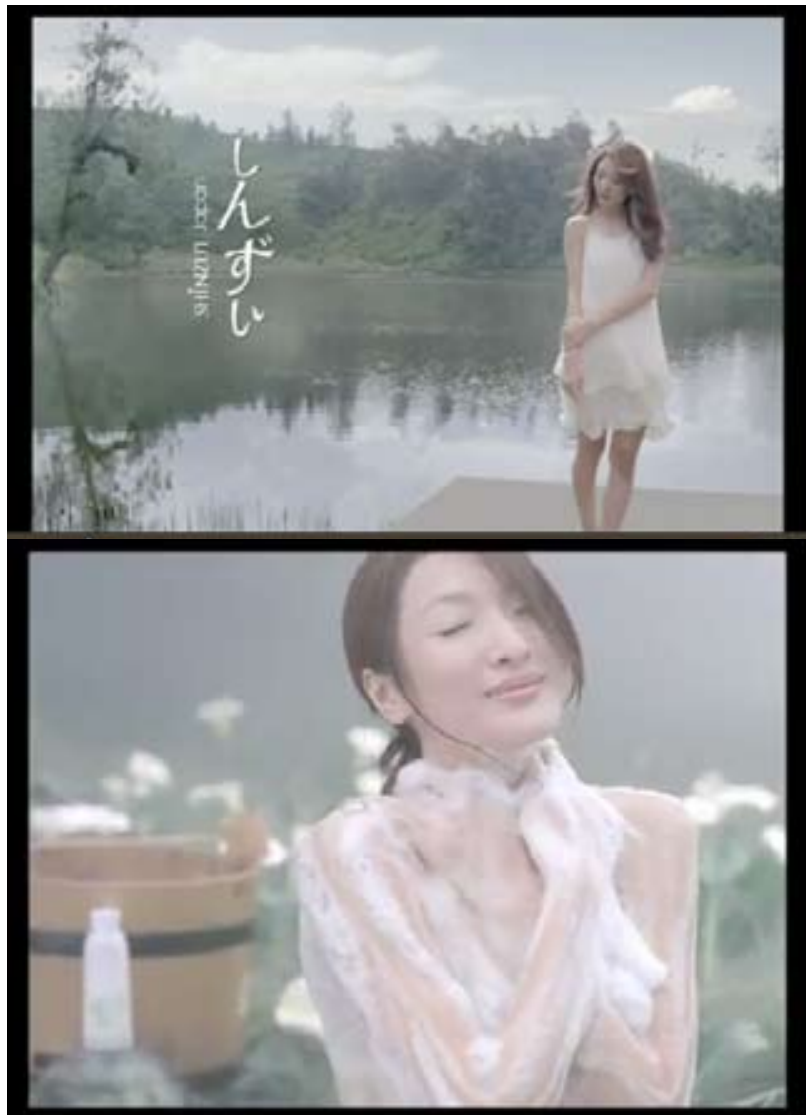
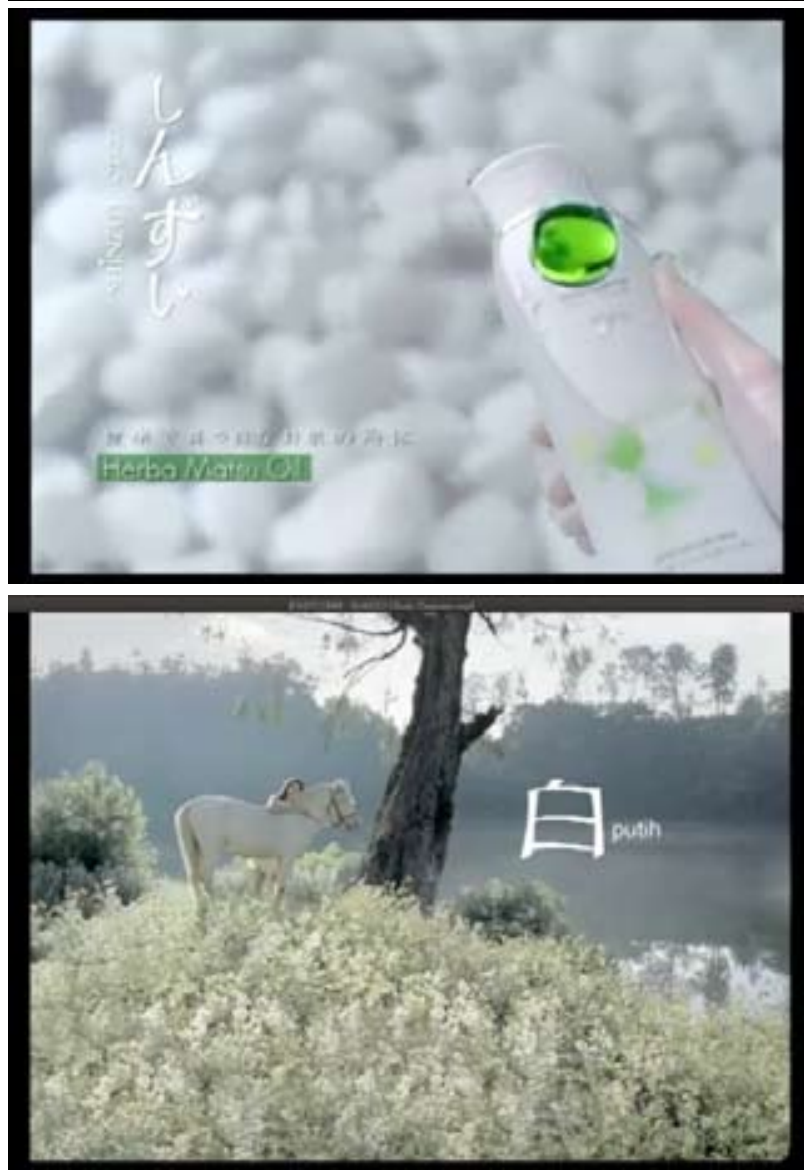


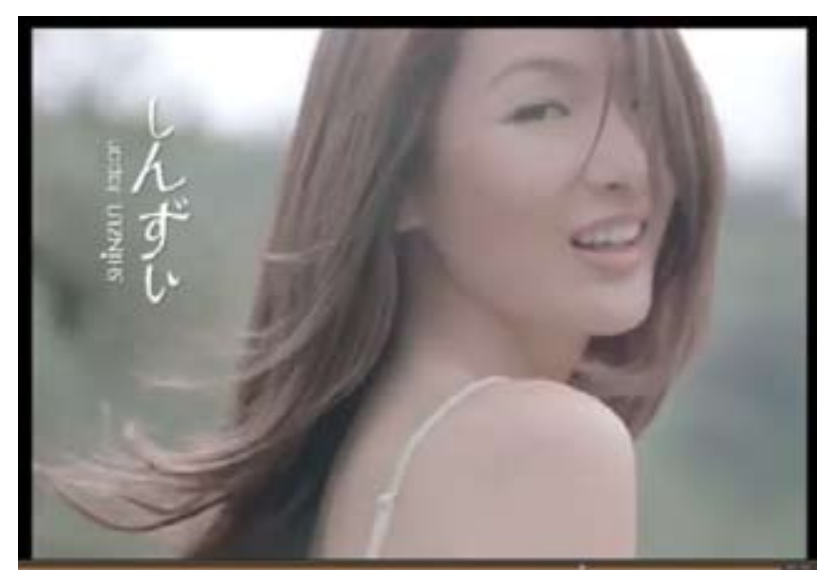

Dalam iklan tersebut terdapat beberapa sceneyangdapatdipecahmenjadienam.Scene pertama menunjukkan identitas produk. Scene kedua menggambarkan kesegaran dan kecantikan perempuan yang dalam iklan diwakili oleh perempuan berwajah Jepang. Scene ketiga menunjukkan visual dan fisik produk secara keseluruhan. Scene keempat proses penggunaan sabun Shinzui, yang kelima menunjukkan perempuan yang cantik setelah menggunakan sabun dan scene keenam sebagai penutup. Setiap scene diberi dubbing penjelasan tentang iklan:

"Shinzui... begitu lembut dan mencerahkan karena kandungan Herba Matsu Oil nya. Shinzui Body Cleanser membuat kulitmu begitu mempesona, seputih wanita Jepang. Karena Putih itu Shinzui..”

\section{Decoding}

Penelitian dilakukan dengan melakukan wawancara mendalam kepada empat responden yang telah memenuhi syarat dalam memahami unit analisis penelitian. Penelitian dilakukan dengan menekankan pada beberapa aspek dibawah ini:

- aspek teknis

- aspek konsep kecantikan

- aspek pengalaman responden.

Aspek teknis dibutuhkan untuk memahami penangkapan pesan responden terhadap iklan Shinzui dan pengalaman menggunakan produk tersebut. Sedangkan aspek konsep kecantikan dibutuhkan untuk menggali analisis resepsi responden tentang konsep kecantikan secara umum sedangkan aspek pengalaman dibutuhkan untuk mengetahui latar belakang responden sehingga peneliti dapat mengerti dengan benar asal dari jawaban tentang konsep kecantikan responden.

\section{HASIL DAN PEMBAHASAN}

\section{Responden Pertama}

\section{Aspek Teknis}

Pada responden pertama, hal yang paling dilihat pada iklan Shinzui ini adalah talent perempuan cantik yang sedang mandi di sungai. Dari segi pengambilan gambar, setting dan properti, responden pertama menyatakan bahwa iklan ini sangat mendukung dengan tema yang diusung oleh produk ini. Penonton atau khalayak seolaholah terbawa dengan suasana "Kejepangan" yang ditampilkan dalam iklan ini. Responden juga menyatakan bahwa produk sabun Sinzhui, batu Jepang, dan Jembatan juga menjadi hal yang menarik, yang menyita perhatian responden.

Responden pertama secara pribadi tidak pernah menggunakan produk sabun mandi yang ada pada iklan tersebut, akan tetapi pernah menggunakan untuk produk Sinzhui yang lainnya. Responden melihat inti pesan dari iklan sabun Sinzhui ini adalah tentang "Pemutihan Kulit". Namun responden pertama tahu betul bahwa kulitnya tidak akan pernah menjadi putih apalagi seputih kulit wanita Jepang. Sehingga responden menyatakan tidak setuju mengenai perihal cantik itu memutihkan kulit seperti kulit wanita Jepang.

\section{Aspek Konsep Kecantikan}

Disisi lain, responden pertama menjelaskan, bahwa dirinya tidak setuju dengan iklan Sinzhui yang me-labeling produknya agar konsumen bisa seputih wanita Jepang. Karena responden pertama tahu betul bahwa kulit sawo matangnya tidak akan berubah walaupun memakai produk Sinzhui. Sehingga menurutnya, standar kecantikan yang dijadikan dalam iklan ini 
sangat tidak cocok. Terlalu mengkotakkan makna kecantikan wanita.

Sedangkan responden pertama sendiri memiliki keyakinan dan pandangan tersendiri mengenai kecantikan. Menurutnya kecantikan adalah tidak melulu soal hal fisik yang bisa dilihat oleh kasat mata. Akan tetapi soal "inner beauty" ada dalam hati dan pikiran wanita. Jadi, haruslah balance antara kecantikan luar dan dalam. Karena wanita juga harus pandai menjaga penampilan luar dirinya, akan tetapi tetaplah memupuk dan menjaga unsur-unsur kebaikan hati yang ada dalam jiwanya.

\section{Aspek Pengalaman Responden}

Dari pengalaman responden pertama, responden menyatakan bahwa secara pribadi tidak pernah melihat iklan sinzhui tersebut muncul di televisi. Dikarenakan jam nonton televisi responden dimulai pukul 10 malam itu pun program kartun untuk anak-anak. Televisi yang dimiliki oleh responden adalah model TV berlangganan, sehingga untuk kuantitas iklannya pun tidak banyak, sangat berbeda dengan TV swasta nasional selama ini, dimana durasi iklan bisa lebih besar daripada program acara televisinya.

Responden pertama pernah bereksperimen sewaktu kecil tentang kecantikan. Sewaktu responden masih kecil, responden pertama mendapatkan informasi dari mamanya bahwa menggunakan handbody itu dapat memutihkan kulit. Akan tetapi karena masih kecil dan belum paham, maka responden malah memakai handbody pada wajahnya. Tentu hal ini mengakibatkan bintik-bintik putih pada kulit wajah responden pertama.

Responden pertama menambahkan bahwa ada iklan yang paling disukai yang pernah ia tonton, yaitu iklan TRI ALWAYS ON. Iklan ini dianggap menarik oleh responden dikarenakan iklan tri ini berhasil menyampaikan makna "kebebasan" kepada responden. Selain itu, iklan MIZONE yang edisi baru 2016 dengan backsound DJ di tempat fitnes juga menjadi iklan favorit responden. Hal ini dikarenakan, bahwa iklan tersebut memberikan pandangan dan kesan yang berbeda bahwa dalam iklan minuman berenergi itu, penyajiannya tidak melulu soal badan lesu kemudian minum minuman berenergi jadi segar kembali.

Sedangkan iklan aneh dan dianggap jelek responden adalah IKLAN MASTIN. Iklan mastin dianggap kurang begitu menarik bagi respondenpertamadikarenakanpengulangan terus menerus ketika iklan tersebut tayang. Padahal responden menganggap hal itu tidak perlu.

\section{Responden Kedua}

\section{Aspek Teknis}

Responden kedua juga melihat sosok wanita cantik, putih dan seksi dalam iklan Sinzhui ini. Dari segi pengambilan gambar, backsound, danjugapropertiatausettingyang ditampilkan, sangat sesuai dan bersinergi untuk mendukung iklan sabun mandi ini. Sangat marketable menurutnya. Responden kedua pernah menggunakan produk Shinzui walaupun tidak memberikan dampak putih pada kulitnya. Responden memberikan saran, seharusnya pada iklan tersebut ditampilkan pula pesan bahwa "hasil berbeda pada setiap orang". Karena notabene, produk tersebut mengisyaratkan agar mempercantik diri melalui memutihkan diri seputih wanita jepang, lha padahal secara realistis iklan tersebut tampil pula di Indonesia dengan kuantitas market yang lebih besar dibanding negara asal produknya.

\section{Aspek Konsep Kecantikan}

Responden kedua melihat pesan iklan ini adalah tentang standar kecantikan, yaitu cantik itu putih dan putih itu Sinzhui. menurutnya, hal ini sesuai dengan trend mode kecantikan masa kini, yaitu kalau di Asia kiblat kecantikan adalah negara Korea dan Jepang. Responden kedua pernah menggunakan produk sabun mandi Sinzhui ini. Akan tetapi hal ini bukan dikarenakan efek dari setelah melihat iklan tersebut, tetapi lebih karena rasa penasaran ketika sedang berbelanja di supermarket. Responden menyukai sabun mandi Sinzhui dari segi keharuman produk tersebut. 
Responden kedua juga menambahkan bahwa jikalau melihat iklan yang hampir serupa dengan tema cantik itu putih, responden melakukan survey tersendiri. Yaitu dengan cara bertanya langsung kepada teman-teman terdekatnya apakah jika memakai produk $\mathrm{X}$ memang memberikan hasil putih atau tidak. Dan jawaban dari teman-teman responden pun bermacammacam, ada yang memang berhasil dan ada pula yang tidak sama sekali berpengaruh. Responden malah menjadi "kepo" sendiri mengenai produk $\mathrm{X}$ tersebut.

Dikarenakan responden kedua lebih sering tampil di layar televisi sebagai pembawa acara pula (selain Kepala Program). Tentunya hal ini membuat dirinya untuk dituntut menjadi wanita cantik yang putih, tinggi, langsing, rambut lurus, dsb. Akan tetapi karena standar kecantikan di depan kamera yang sedemikian kompleks dihadapi oleh responden setiap hari, justru membuat responden malah mampu menerima kekurangan diri dan kecantikannya. Responden lebih terbuka wawasannya tentang perihal kecantikan. Walaupun tidak memungkiri, Responden kedua cukup setuju bahwa memiliki kulit putih merupakan bagian dari indikator wanita cantik dan menarik.

Selain itu, Kecantikan menurut responden kedua adalah tidak hanya soal fisik, tetapi juga memiliki rasa percaya diri dan mampu memberdaya diri sesuai dengan apa yang wanita itu mampu.

Responden kedua, pertama kali melihat iklan Sinzhui ini di Youtube. Walaupun di televisi juga pernah. Responden menonton televisi setelah pukul 7 malam. Itupun sambil melakukan kegiatan lain seperti makan, ngobrol, bbm-an, dll.

\section{Aspek Pengalaman Responden}

Responden kedua memiliki pengalaman sewaktu kecil pernah bermain-main dengan produk kecantikan yaitu bedak dan lisptik. Hal ini dikarenakan, responden kedua meniru perilaku dari sang ibunda setiap kali berdandan. Sedangkan ketika SMP, responden kedua lebih melakukan ritual kecantikan diri dengan cara meniru teman- teman sebayanya tentang apa yang sedang hits di kala itu, seperti produk vaseline.

Iklan yang paling di ingat oleh responden adalah iklan Cimory edisi anak kecil dan ada sapi. Menurut responden justru ketidakkoherenan antara anak kecil dan sapi justru hal yang paling membekas dibenak oleh reponden. Sedangkan iklan yang dianggap aneh adalah iklan parfum Gatsby yang dibawakan oleh Adipati Dolken. Hal ini dikarenakan iklan ini kurang realistis. Iklan Gatsby ini memberikan gambaran bahwa kalau kita wangi, maka kita dapat melakukan apa saja dengan sukses. Iklan apik menurut responden kedua adalah iklan Axis. Mengapa demikian? Responden menyatakan bahwa iklan Axis sukses dalam menyampaikan pesannya. Apalagi dikemas dengan konsep yang sedikit konyol, tentunya semakin membuat menarik.

\section{Responden Ketiga}

\section{Aspek Teknis}

Hal yang dilihat oleh responden ketiga dalam iklan ini adalah produk sabun Sinzhui. Menurut responden ketiga, secara pengambilan gambar, latar, dan properti tergolong bagus, akan tetapi responden ketiga melihat ada hal yang janggal dalam iklan ini yaitu dengan hadirnya kuda pada detik-detik scene terakhir. Responden tidak mengerti maksud dari dihadirkannya kuda ini. Responden pernah menggunakan produk dari sinzhui tersebut namun hanya satu kali saja karena setelah dicoba, produk sabun tersebut membuat kulit responden menjadi lebih kering.

\section{Aspek Konsep Kecantikan}

Menurut responden ketiga, definisi cantik itu tidak harus putih. Karena bagi responden kecantikan adalah sesuatu yang tidak harus diprioritaskan, masih banyak hal-hal lain yang perlu dijadikan indikator seorang perempuan itu cantik atau tidak seperti kecerdasan, talenta, dll. Responden pernah melihat iklan Sinzhui ini melalui televisi. Sehingga responden ketiga, menyatakan tidak setuju terhadap isi pesan iklan Shinzui tersebut. 


\section{Aspek Pengalaman Responden}

Iklan yang paling tertanam dibenak responden ketiga adalah iklan mastin karena iklan ini sering muncul di televisi. Iklan yang dianggap jelek oleh responden ketiga adalah iklan snack kingkong yang dibawakan oleh raffi ahmad. Karena responden merasa bosan melihat artis raffi yang sering tampil di televisi. Sedangkan iklan bagus menurut responden ketiga adalah semua iklan yang menggunakan tema ramadhan dan lebaran.

Frekuensi responden dalam menonton televisi tergolong rendah yaitu hanya berkisar satu jam saja per hari, hanya menonton program selebrita pagi atau kilasan berita dari channel metro TV saja. Responden sering mengganti channel ketika sesi commercial break tiba. Karena pada dasarnya responden tidak menyukai iklan, dirasa sangat membosankan.

\section{Responden Keempat}

\section{Aspek Teknis}

Responden keempat melihat produk sabun yang dapat membuat kulit lembut. Responden keempat sangat tertarik melihat iklan ini, karena dari segi pengambilan gambar, backsound musik yang mengiringi, dan nuansa sejuk dari iklan tersebut tergolong keren dan sesuai dengan negara Jepang. Responden juga melihat hal janggal dalam iklan ini adalah dengan hadirnya seekor kuda. Kenapa bukan objek awan yang putih juga.

Menurut pengakuan responden keempat ini, setelah melihat iklan tersebut di televisi, responden memutuskan untuk membeli produk tersebut. Responden tidak kecewa dengan produk ini karena selain dapat membuat kulitnya menjadi lebih putih, produk ini juga memiliki keharuman yang disukai oleh responden. Hal ini mengindikasikan bahwa pesan iklan Shinzui diterima dengan baik oleh responden keempat.

\section{Aspek Konsep Kecantikan}

Arti kecantikan menurut responden adalah bersih. Bukan putih. Karena dengan memenuhikebersihan,sudahdapatdikatakan kalau perempuan itu cantik. Responden melihat iklan Sinzhui tadi ada di televisi. Jam tayang responden menonton televisi adalah dari mulai setelah magrib hingga malam. Dan full ditonton. Kalau commercial break tiba, responden tidak mengganti channel akan tetapi juga tidak terlalu memperhatikan.

\section{Aspek Pengalaman Responden}

Sewaktu kecil, responden pernah memiliki eksperimen tentang kecantikan yaitu membuat lulur dari bengkoang yang dilembutkan sendiri. Dan mewarnai kuku dengan menggunakan daun pacar. Iklan yang paling disukai oleh responden adalah iklan sprite yang dibawakan oleh ahmad dhani. Sedangkan iklan yang tidak disukai adalah iklan partai perindo. Hal ini dikarenakan terlalu memaksakan dalam pencitraan diri Heru Tanoe, dan iklannya sering diputar. Sehingga membuat bosan responden.

\section{Responden Kelima}

\section{Aspek Teknis}

Pada responden kelima, hal yang paling diingat pada iklan Shinzui ini adalah produk sabun yang menawarkan kulit putih ala wanita Jepang, dimana khalayak audience nya adalah masyarakat Indonesia yang notabenya memiliki kulit sawo matang.

Produk sabun tersebut mengambil keutungan ditengah paradigma kaum hawa di Indonesia yang masih cenderung memiliki mindset bahwa cantik itu adalah putih. Oleh karenanya, produk sabun tersebut mampu memanfaatkan celah dari paradigma tersebut hingga akhirnya, positioning produk tersebut di benak masyarakat berhasil membangun brand awarness, bahwa apabilaingin memiliki putih, pakai saja produk Shinzui.

Responden kelima setuju, bahwa dari segi pengambilan gambar, setting, talent, dan properti, iklan ini sangatlah memiliki konsep yang jelas mengenai konsep kecantikan. Unsur audio visual pun tampak sangat mendukung dalam membangun brand produk sabun tersebut, dimana makna tersirat dari sebuah konsep kecantikan 
yang dibangun oleh produk tersebut adalah wanita cantik berkulit putih, anggun, kalem, menyejukkan (memanjakan) mata, dan berperilaku lembut. Dan memang sifat-sifat itulah yang seharusnya dimiliki oleh wanita.

Responden kelima secara pribadi pernah dan memang sedang menggunakan produk sabun mandi yang ada pada iklan tersebut. Responden melihat inti pesan dari iklan sabun Sinzhui ini adalah tentang "Wanita Cantik yang Putih". Responden paham bahwa kulitnya tidak akan pernah menjadi putih apalagi seputih kulit wanita Jepang. Namun sebagai salah satu publik figureyang memiliki profesi sebagai presenter, responden setuju bahwa salah satu simbol profesionalisme dari seorang yang tampil di layar kaca adalah dengan tampil menarik secara fisik. Tampil menarik tersebut, salah satu point nya adalah memiliki kulit bersih dan putih, walaupun tidak perlu seputih wanita Jepang.

\section{Aspek Konsep Kecantikan}

Responden kelima dengan jelas menyatakan bahwa dirinya setuju dengan iklan Sinzhui yang membranding produknya agar konsumen bisa seputih wanita Jepang. Walaupun responden paham, bahwa kulit sawo matangnya tidak akan berubah seputih wanita Jepang dengan memakai produk Sinzhui. Akan tetapi responden meyakini bahwa produk Shinzui tersebut, merupakan salah satu produkyang tergolong "berkhasiat" atas perubahan kulitnya, "setidaknya "tidak bertambah kusam, malah cenderung mencerahkan".

Responden kelima sendiri memiliki keyakinan dan pandangan tersendiri mengenai kecantikan. Kecantikan memang tidak dangkal definisi nya hanya sebatas fisik saja. Namun karena profesi responden yang dilihat oleh pemirsa / audience / khalayak umum, mau tidak mau harus menjunjung tinggi nilai-nilai profesionalisme dengan salah satunya menjaga penampilan fisik yang tentu saja, di imbangi pula dengan kualitas kecerdasan emosional dan sosial.

\section{Aspek Pengalaman Responden}

Dari pengalaman responden kelima, responden menyatakan bahwa pernah melihat iklan sinzhui tersebut muncul di televisi. Dikarenakan responden termasuk orang media yang tentu saja memantau program-program dan iklan yang ada pada media siaran di televisi.

Responden kelima pernah memiliki pengalaman sewaktu kecil tentang kecantikan. Sewaktu responden masih kecil, responden kelima pernah mencoba lipstik dan bedak milik tantenya kemudian berkaca di depan cermin dan menirukan tingkah laku pembawa acara berita yang tampil di layar kaca. Responden kelima memang sangat menyukai dunia penyiaran, karena ibu dari responden juga bekerja sebagai pegawai media di salah satu stasiun TV milik pemerintah. Sehingga barangkali menularkan virus "penyiarannya" kepada responden.

Responden kelima menambahkan bahwa ada iklan yang paling disukai yang pernah ia tonton, yaitu iklan BAYGON dimana seorang ibu dengan tangguhnya melindungi keluarga dari serangan gigitan nyamuk. Iklan ini dianggap menarik oleh responden dikarenakan iklan BAYGON ini berhasil menyampaikan makna "supermom" kepada responden. Hal ini dikarenakan ibu dari responden adalah seorang single parent yang juga tangguh dalam mengurus dan melindungi keluarga. Iklan BAYGON inilah yang mengingatkan responden terhadap sosok ibu-nya yang patut ditiru ketangguhannya terutama demi keluarga.

Sedangkan iklan aneh dan dianggap jelek responden adalah BUKA LAPAK yang membawa grup NETRAL sebagai bintang iklannya. Iklan BUKA LAPAK dianggap kurang begitu menarik bagi responden karena dianggap menggangu dan berisik dengan backsound yang mengiringinya.

\section{Respon Keenam}

\section{Aspek Teknis}

Responden keenam juga melihat sosok wanita cantik, putih dan lembut dalam iklan Sinzhui ini. Dari segi pengambilan gambar, pemilihan talent, backsound, dan juga propertiatau settingyang ditampilkan, sangat 
bersinergi satu sama lain sehingga tidak keluar dari konsep iklan yang menyuguhkan kecantikan khas wanita Jepang.

Responden kedua pernah menggunakan produk Shinzui walaupun tidak memberikan dampak putih yang cukup signifikan pada kulitnya. Namun responden memberikan keterangan cukup puas terhadap kualitas produk sabun Shinzui tersebut. Walaupun produk Shinzui tersebut bukan daftar pertama pilihan responden terhadap minat beli produk sabun, namun Shinzui adalah pilihan atau alternatif kedua setelah merk sabun "CITRA".

Responden termasuk dalam kategori orang yang ikut "mengamini" bahwa penampilan fisik yang menarik perlu diprioritaskan seorang perempuan, terlebih apabila profesinya bekerja dan berkarya adalah dengan melibatkan interaksi banyak orang. Responden menyatakan bahwa alangkah lebih baik jika kecantikan fisik juga diperhatikan, bukannya diabaikan.

Menjadi cantik di sini bukan berarti harus selalu mengenakan make-up tebal yang sampai membuat orang pangling atau sampai melakukan operasi plastik, namun dengan perawatan diri dan make-up yang natural saja. Pada dasarnya wanita dalam keadaan apapun, cantik adanya, dengan bantuan make-up dan perawatan, kecantikan akan lebih terpancarkan. Terlebih kaum hawa adalah makhluk yang paling indah dan alangkah lebih indah jika menghargai anugerah tersebut dengan merawatnya sebaik mungkin.

\section{Aspek Konsep Kecantikan}

Responden yang keenam sebenarnya adalah seorang yang sangat interest terhadap produk kecantikan Lipstik. responden bisa menghabiskan ratusan ribu bahkan totalnya bisa jutaan hanya untuk mengkoleksi berbagai macam merk lipstik dari yang lokal sampai merk import. Dari yang Matte, Satin, Moisturizing, Liquid, Cream, Frosted, hingga Long Wearing.

Responden keenam melihat pesan iklan ini adalah tentang standar kecantikan, yaitu cantik itu putih ala Sinzhui. Menurutnya sah- sah saja seorang perempuan berkeinginan memiliki kulit putih agar terlihat cantik, walaupun kulit putih versi wanita Indonesia tidak bisa seputih wanita Jepang (kecuali apabila suntikputih, operasi, dsb). Responden juga menambahkan, bahwa kecantikan fisik namun juga harus diimbangi dengan kecantikan hati, pikiran, dan attitude. Jadi tidak hanya casing saja yang di upgrade, akan tetapi software nya juga.

Menurutnya, dengan mempercantik dan merawat diri adalah bentuk menghargai jati diri sebagai wanita, yang dianugerahi kecantikan dan keindahan dari Yang Maha Kuasa. Responden menyadari bahwa diri seorang wanita itu berharga. Dengan makeup bukan berarti seperti memakai topeng, namun mengeluarkan kelebihan sebagai wanita yang selama ini terpendam. Tujuan utama lahirnya make-up serta produk kecantikan adalah agarwanita semakin cantik dan mempesona, bukan sebagai topeng yang menutupi wajah yang sesungguhnya.

Menggunakan produk kecantikan yang disertai dengan pemakaian make up, sejatinya berfungsi untuk menonjolkan kelebihan yang dimiliki wajah kita dan mengoreksi yang tampak kurang. Terlebih jika responden adalah seorang produser on air TV swasta nasional yang notabennya harus memberikan contoh yang baik kepada bawahannya, terutama kepada presenter atau Co Host di program acaranya di KVision \& GG Intersport.

Responden keenam, pertamakalimelihat iklan Sinzhui ini di Youtube. Walaupun di televisi juga pernah. Responden menonton televisi mulai pukul 9 pagi. Itupun sambil melakukan kegiatan lain seperti brifing atau brain storming program on air.

\section{Aspek Pengalaman Responden}

Responden keenam memiliki pengalaman sewaktu kecil pernah bermain-main dengan produk kecantikan yaitu lisptik. Responden mulai mengenal make up atau produk kecantikan sewaktu SMP. Hal ini dikarenakan responden sangat suka melihat warna lipstik yang warna warni, yang bisa dioleskan di bibir. 


\section{Operasionalisasi Konsep}

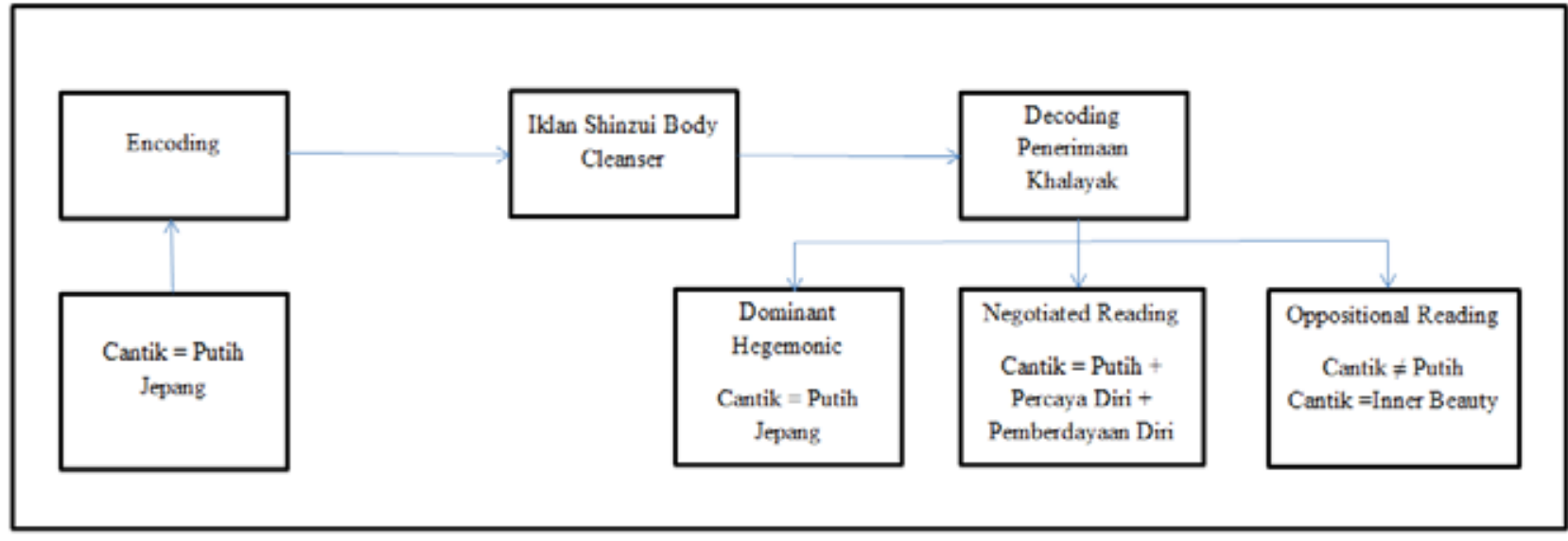

Iklan yang paling di ingat oleh responden adalah iklan-iklannya Aqua yang versi \#adaaqua, iklan-iklannya Bukalapak, dan iklan-iklannya Rayamana yang versi \#kerenhaksegalabangsa. Karena, iklaniklan tersebut memiliki konsep unik, agak nyeleneh, namun fresh \& menghibur.

Iklan yang kurang di sukai, yaitu iklan Tori Tori Cheese Cracker, karena iklannya agak ngeselin \& nyebelin tapi, disisi lain iklan itu jadi mudah diingat dan terngiang-ngiang di kepala penontonnya.

\section{SIMPULAN}

Berdasarkan teknik pengumpulan data berupa wawancara, maka dapat disimpulkan bahwa tiga diantara enam responden, masuk dalam kategori Negotiated Reading, dua diantara enam responden, menyatakan Oppositional Reading terhadap iklan ini. Dan satu responden berada pada posisi Dominant Hegemonic.

Respondenke-empat,kelimadankeenam berada pada posisi Dominant Hegemonic yang menyatakan bahwa pesan iklan Shinzui tersebut memiliki makna memutihkan kulit, seputih wanita Jepang. Mereka setuju dengan penyajian konsep kecantikan yang ditampilkan di iklan tersebut. Sehingga responden melakukan tindakan selanjutnya yaitu berupa pembelian produk yang ada dalam iklan Shinzui.

Responden kedua yaitu Kepala Program, berada pada posisi Negotiated Reading. Dengan kata lain, responden juga setuju mengenai indikator wanita cantik itu berkulit putih, (dikarenakan hal ini untuk keperluan profesionalisme bekerja dalam berpenampilan di depan kamera). Akan tetapi Responden ketiga juga menambahi bahwa wanita itu juga harus memiliki rasa percaya diri dan mampu memberdaya diri.

Responden pertama dan ketiga yaitu Reporter Radio dan Accounting pada posisi Oppositional Reading, yaitu tidak setuju mengenai konsep kecantikan yang diperlihatkan dalam iklan Shinzui tersebut. Karena pada dasarnya mereka memiliki ideologi tersendiri mengenai kecantikan. Responden pertama menyatakan bahwa kecantikan tidak hanya mengenai hal fisik, akan tetapi juga “inner beauty". Sedangkan responden ketiga menyatakan bahwa kecantikan merupakan kepemilikan hal-hal positif seperti kecerdasan, talenta, dan lainlain. 


\section{DAFTAR PUSTAKA}

Abdullah, Irwan. (2006). Studi Tubuh, Nalar dan Masyarakat: Perpektif Antropologi. Yogyakarta: Tici Press.

Barker, Chris. (2004). The Sage Dictionary of Cultural Studies. London: Sage Publication

Britton, Ann Marie. (2012). The Beauty Industry's Influence on Woman in Society. University of New Hampshire Scholars' Repository. Fall. Honors Theses.

Burhan, M Bungin. (20o8). Konstruksi Sosial Media Massa: Kekuatan Pengaruh Media Massa dan Keputusan Konsumen serta Kritik Terhadap Peter L. Berger E Thomas Luckmann. Jakarta: Kencana

Channey, David. (1996). Lifestyles. London: Routledge

Downing, John, Ali Mohammadi dan Annabela Sreberny Mohammadi. (1990). Questioning The Media: A Critical Introduction. California: Sage Publication, Inc.

Hall, Stuart, (1981), Encoding/Decoding, dalam Stuart Hall, A. Lowe, dan Paul Willis (eds.), Culture, Media, Language, London: Hutchinson.

Jeffkins, Frank. (1996). Advertising (Periklanan). Jakarta: Airlangga

Kasiyan,. (2008). Manipulasi dan Dehumanisasi Perempuan dalam Iklan. Yogya: Ombak

Littlejohn, Stephen W and Karen A Foss. (2005). Theories of Human Communication. California: Sage Publication

McQuail, Denis. (2002). Teori Komunikasi Massa. London: Sage Publications.

Pawito. (2007). Penelitian Komunikasi Kualitatif. Yogyakarta: LkiS

Prabasmoro, Aquarini Priyatna. (2003). Becoming White: Representasi Ras, Kelas, Feminitas, dan Globalisasi dalam
Iklan Sabun. Yogyakarta: Jalasutra

Sudiarta,IWayan.(2006). RekonstruksiVisual Konsep-Konsep Kecantikan Tradisional WanitaBalidanManifestasinyadiDalam Kehidupan Masyarakat Bali Masa Kini. Tesis S2. Program Studi Kajian Budaya. Pasca Sarjana Universitas Udayana.

Winarni, Rina Wahyu. (2009). Representasi Kecantikan Perempuan dalam Iklan. Jakarta: Jurnal Deiksis Program Studi Desain Komunikasi Visual Universitas Indraprasta PGRI Jakarta

Yulianto, Vissia Ita. (2007). Pesona Barat. Analisa Kritis Historis tentang Kesadaran Warna Kulit di Indonesia. Yogyakarta : Jalasutra

\section{Sumber Internet:}

Putihitushinzui.com. (2012). Shinzui Body Cleanser. diakses tanggal 12 Juni 2016.

Anonim. Dikutip dari https:// e d u c 5102 . wikis paces.com/ Cultural+Studies+(Hall) diunduh tanggal 31 Maret 2017 pukul 11.32 WIB

Bisniskeuangan.kompas.com. (2012). Top Brand Award Kategori Whitening Soap. diakses tanggal 12 Juni 2016. 